\title{
Note \\ Effects of Ergocornine on Reserpine-induced Lactogenic Response of Male Rat Mammary Glands
}

\author{
Yasumasa ARAI, Yoshinide SUZUKI and SAKae MASUDA \\ Department of Anatomy, Juntendo University School of Medicine, \\ Hongo, Tokyo
}

\section{Synopsis}

\begin{abstract}
Mammary lactogenic response was obtained in the male rat following a single injection of reserpine $(1 \mathrm{mg} / \mathrm{kg})$. The lactogenic effect of reserpine was rather long-lasting and the response of the mammary glands was biphasic. As previously reported (Arai and Suzuki, 1971), the initial peak of the lactogenic response was recognized on day 2, the second one around day 8. Administration of ergocornine $(1 \mathrm{mg} / \mathrm{rat})$ concurrently with reserpine inhibited the initial phase of lactogenic response when autopsied on day 2. The secondary lactogenic response was also inhibited when ergocornine was given on day 4 or day 6 and autopsied on day 8 , but not inhibited when ergocornine was given concurrently with reserpine and autopsied on day 8 . These results suggest that ergocornine acts at a different level from that of the lactogenic action of reserpine to prevent pituitary prolactin release, and also suggest that alterations in the hypothalamus caused by reserpine may be primarily responsible for the biphasic release of pituitary prolactin in the male rat.
\end{abstract}

Prolactin secretion in the male rat has been demonstrated under certain conditions, although its physiological significance is not clear in the male (Zeilmaker, 1963; De Voe et al., 1965; Deis, 1967; Ben-David, 1968; Danon et al., 1970). We have recently reported that milk secretion in the male mammary gland can be initiated within 2 days of a single injection of reserpine (Arai et al., 1970). This lactogenic changes in the male mammary gland was biphasic; two distinct phases exist in the time course of changes after a single injection of reserpine, i.e. the initial phase roughly covering the first 4 days, followed by the second phase (from day 5 to 14) (Arai and Suzuki, 1971). The cause of this biphasic response is not clear, but it would be suggested that the response may reflect alterations in the hypothalamic pituitary mechanisms control-

Received for publication October 23, 1971. ling prolactin secretion. In the present study, as one step to elucidate the mechanisms, the effect of ergocornine, which is claimed to inhibit prolactin secretion (Shelensnyak, 1954), on reserpine-induced lactogenic changes in the male mammary gland was examined by injecting this drug at various intervals following reserpine.

\section{Materials and Methods}

Male Wistar rats (57-60 days old, weighing 180 $200 \mathrm{~g})$ purchased from Fuji Animal Farm were used in the present study. The animals were divided into 9 treatment-groups (Fig. 1). A single subcutaneous injection of reserpine (1 mg Triserpine, Torii Pharmaceutical Co., Tokyo/kg) was given on day 0 (The day of reserpine injection was defined as day 0). Ergocornine methanesulphonate $(1 \mathrm{mg} / 0.2 \mathrm{cc}$ saline/rat) was injected subcutaneously according to the experimental designs shown in Figure 1. At autopsy, the inguinal mammary pads were fixed in Bouin's fluid 


\section{Experimental Design}

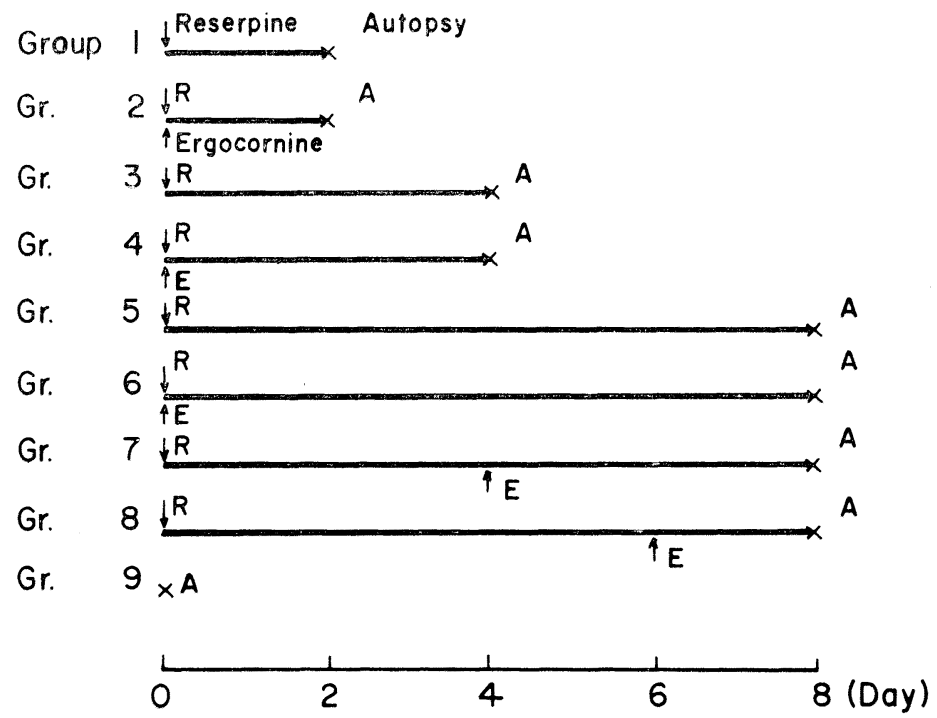

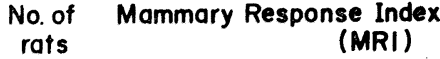

10

$3.1 \pm 0.2$

$9 \quad 1.2 \pm 0.2$

9

$1.2 \pm 0.3$

6

$1.5 \pm 0.3$

8

$2.9 \pm 0.1$

5

$2.7 \pm 0.1$

10

$2.0 \pm 0.2$

12

$1.5 \pm 0.2$

6

Fig. 1. Experimental design and effect of ergocornine on reserpine-induced mammary lactogenic response in the male rat. Arrow indicates the time of injection. The day of reserpine injection $=$ day $0, \mathrm{R}=$ reserpine, $\mathrm{E}=$ ergocornine, $\mathrm{A}=$ autopsy. For the dosage of Rand E, see text.

and embedded in paraffin wax. Serial sections, cut to at $10 \mu$ in thickness, were stained with $\mathrm{H}$-E. The evaluation of lactogenic response was made histologically according to the mammary response index (MRI), which was a modification of Meites and Nicoll (1959) for the male mammary gland (see Arai and Suzuki, 1971). The MRI was as follows; 0, end buds or small alveoli without secretion; 1 , small alveoli with secretion; 2, slight alveolar enlargement with secretion; 3 , distended alveoli with milky secretion; 4, greatly distended alveoli with milky secretion in most parts of the sections, almost comparable to a lactating gland. The ratings are in units of 0.5 .

\section{Results}

The results are summarized in Figure 1. As reported previously (Arai and Suzuki, 1971), the lactogenic effect of a single injection of reserpine was long-lasting and the mammary response was biphasic. Two days after the injection of reserpine (day 2) the mammary glands showed a marked lobuloalveolar development; the alveoli and ducts were greatly distended with milky secretion. The MRI of this group (Group 1) was $3.1 \pm 0.2$. Four days after the injection (day 4) the mammary secretory activity declined and regression of the alveoli was noted (Group 3, MRI = $1.2 \pm$ $0.2)$. However, the mammary secretory activity increased again 8 days after the injection (Group 5)*. This secondary lactogenic response was also characterized by the distention of alveoli with milky secretion (MRI $=2.9 \pm$ 0.1 ), an appearance comparable to that of Group 1.

When ergocornine was administered concurrently with reserpine, the initial lactogenic

\footnotetext{
* In preliminary experiments, the mammary secretory activity began to increase around day 6 , and the maximal activity was obtained on day 8 , but the activity disappeared by day 14 .
} 
response was effectively inhibited; no development of ducts and alveoli was found in Group 2 rats sacrificed on day 2 (MRI $=1.2$ \pm 0.2 ). A similar low mammary response was also obtained in rats of Group 4 sacrificed 4 days after the injections of reserpine and ergocornine (MRI $=1.5 \pm 0.3)$. In contrast, the secondary lactogenic response could not be inhibited when autopsy was delayed until 8 days after the injections of reserpine and ergocornine (Group 6). The MRI was $2.7 \pm$ 0.1 , and not significantly different from that of Group 5. The histology was also similar to that of Groups 1 and 5. Ergocornine was administered 4 or 6 days after the injection of reserpine in order to determine whether the secondary lactogenic response could be inhibited. A clear inhibition of the secondary lactogenic response was obtained by the injection of ergocornine on day 6 (Group 8, MRI $=1.5 \pm 0.2$ ). An inhibition was also observed in Group 7 rats which were treated with ergocornine on day 4 (Group 7 vs Group $5, p 0.05)$, but the effect was significantly less marked in this group $(\mathrm{MRI}=2.0 \pm 0.2)$ than in Group 8.

\section{Discussion}

Ergocornine has been reported to interrupt pseudopregnancy in the rat (Shelensnyak, 1954; Kisch, 1968), to inhibit nidation (Varavudhi et al., 1966), lactation (Zeilmaker and Carlsen, 1962) and mammary growth (Nagasawa and Meites, 1970; Yanai and Nagasawa, 1970). Recently radioimmunoassays demonstrated that this drug significantly reduced serum and pituitary prolactin levels (Nagasawa and Meites, 1970; Wuttke et al., 1971). In the present study, reserpineinduced lactogenic changes in the male mammary glands were also inhibited by ergocornine injection. All these effects of ergocornine can be explained by its interference with the secretion of pituitary prolactin. Although the prolactin content of the pituitary and the blood was not measured in the present study, biphasic release of prolactin from the pituitary following a single injection of reserpine could be assumed from the mammary lactogenic response. Recently Lu et al. (1970) reported that a single intraperitoneal injection of reserpine markedly elevated serum prolactin within 4 hours, associated with a significant decline in pituitary prolactin concentration. Similar rapid changes in prolactin activity appear to occur during the initial phase of mammary lactogenic response in our rats. For the second phase of lactogenic response, it is possible that prolactin release from the pituitary occurred again later than day 4 , presumably around day 6 , because the injection of ergocornine on day 6 did markedly inhibit the secondary mammary lactogenic response. Although the lactogenic effect of reserpine was apparently long-lasting in the present study, the continued presence of reserpine in the brain tissue might be impossible during the time course of the secondary lactogenic response, because reserpine has been reported to disappear very rapidly from the tissues after the injection (Hess et al., 1956). It would appear, therefore, that reserpine participates in the early stage of this complex process, which eventually results in, or permits, the biphasic changes in the mammary glands.

The fact that administration of ergocornine concurrently with reserpine inhibited the initial lactogenic response but failed to inhibit the secondary one indicates that ergocornine attacks a different site from that of lactogenic action of reserpine to prevent prolactin release. Whether the site of ergocornine action is at the pituitary or the hypothalamic level is still not conclusive (Wuttke et al., 1971). Recently considerable evidence that it acts directly on the pituitary cells has been rapidly accumulated (Zeilmaker and Carlsen, 1962; Pasteels, 1970; Malven and Hoge, 1971; Lu et al., 1971). If that is the case, it is most likely that the primary cause of the biphasic response of the male mammary 
gland after a single injection of reserpine exists in the hypothalamic mechanisms. We suggested in a previous paper (Arai et al., 1970) that the lactogenic effect of reserpine on the male mammary gland was due to its inhibitory action on the hypothalamic cathecholamine activity. Recently we obtained the results that nialamide $(250 \mathrm{mg} / \mathrm{kg}$, a MAO-inhibitor) given on day 6 considerably suppressed the secondary lactogenic response (MRI $=2.3 \pm$ 0.2 , unpublished data). These results suggest that the hypothalamic cathecholamine mechanisms (which may be initially triggered by reserpine) seem to be also responsible for the secondary release of prolactin, which perhaps occurred around day 6. However, we have still no evidence that hypothalamic cathecholamine activity fluctuates biphasically after a single injection of reserpine, associated with biphasic prolactin activity. Therefore, further studies are necessary to define clearly the nature and cause of the biphasic lactogenic response after reserpine injection in the male rat.

\section{Acknowledgments}

We express our thanks to Drs. M. Taeschler and E. Flückiger, Sandoz Ltd., Basel, Switzerland, for ergocornine methanesulphonate. We are also grateful to Sandoz Ltd. of Japan, Tokyo. This study was supported in part by a grant to Y. A. from the Ministry of Education of Japan.

\section{References}

Arai, Y. and Y. Suzuki (1971). J. Endocrinol.
50, 697.

Arai, Y., A. Kubokura, Y. Suzuki and S. Masuda (1970). Endocrinol. Japon. 17, 441. Ben-David, M. (1968). J. Endocrinol. 41, 377. Danon, A., C. P. Weller and G. S. Sulman (1970). Ibid. 48, 365.

Deis, R. P. (1967). Acta Physiol. Lat. Am. $17,115$.

De Voe, W. E., V. D. Ramirez and S. M. McCann (1965). Endocrinology 78, 158.

Hess, S. M., P. A. Shore and B. B. Brodie (1956). J. Pharmacol. Exp. Therap. 118, 84.

Kisch, E. S. (1968). J. Reprod. Fert. 17, 221.

Lu, K. H., Y. Amenomori, C. L. Chen and J. Meites (1970). Endocrinology 87, 667.

Lu, K. H., Y. Koch and J. Meites (1971). Ibid. 89, 445.

Malven, P. V. and W. R. Hodge (1971). Ibid. 88, 445.

Meites, J. and C. S. Nicoll (1959). Ibid. 65, 572. Nagasawa, H. and J. Meites (1970). Proc. Soc. Exptl. Biol. Med. 135, 469.

Pasteels, J. (1970). Arch. Int. Pharmacodyn. 186, 195.

Shelensnyak, M. C. (1954). Am. J. Physiol. 179, 301.

Varavudhi, P., B. L. Lobel and M. C. Shelensnyak (1966). J. Endocrinol. 34, 425.

Wuttke, W., E. Cassell and J. Meites (1971). Endocrinology 88, 737.

Yanai, R. and H. Nagasawa (1970). J. Nat. Cancer Inst. 45, 1105.

Zeilmaker, G. H. (1963). Acta Endocrinol. 43, 246.

Zeilmaker, G. H. and R. A. Carlsen (1962). Ibid. 41, 321. 